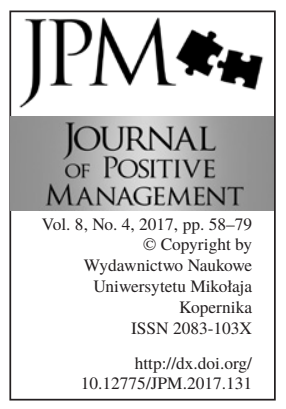

\title{
HOW MUCH DO LEADERS SEEK TO BE INFLUENCED? THE CONCEPT OF SOCIAL INFLUENCE IN REVERSE IN REVERSE
}

\author{
${ }^{a}$ Andrzej Nowak, ${ }^{b}$ Agata Zabłocka, ${ }^{c}$ Ryszard Praszkier \\ ${ }^{\mathrm{a}, \mathrm{c}}$ University of Warsaw, The Robert B. Zajonc \\ Institute for Social Studies, Warsaw, Poland \\ ${ }^{\mathrm{b}}$ University of Social Sciences and Humanities, Warsaw, Poland \\ a e-mail: andrzejn232@gmail.com \\ be-mail: azablocka@swps.edu.pl \\ ce-mail: ryszardpr@gmail.com
}

\begin{abstract}
Purpose: Traditionally, the effects of social influence have been delineated in terms of "leaders" exerting influence over "followers." Here we propose a new concept of social influence in which the leaders are influenced and, in fact, actively seek out that influence and build personal support networks that generate that influence.

Approach: To examine the concept, we conducted both pilot $(\mathrm{N}=42)$ and main studies $(\mathrm{N}=113)$. The pilot study showed that leaders organize diverse support networks based on three major traits of the influence-givers: their competence, moral standards and creativity.

Findings: The research confirmed that leaders cultivate five types of individual support networks or influence-providers: family and close friends, professional connections, colleagues and peers (mostly relating to leisure and entertainment), social engagement, and a local/neighborhood network.

The research revealed several dependencies between the subjects' occupation and their expectations from the influence-providers. We also documented that leaders seek basically two kinds of individual support: support from individuals from whom they expect low-order processed information, i.e., facts and data; (type A), and support from individuals from whom they expect high-order, processed information, i.e., opinions, advice, strategies and predictions; (type B). It also confirmed that selection of type A supporters is primarily based on competencies and type B supporters are typically selected based on moral standing and creativity.

Implications: This article will empower leaders to better understand the value of their support networks, also to organize the flow of received information.

Value/Originality: We are presenting an original concept of social influence in reverse, broadening the cognition of social influence in positive management.
\end{abstract}

Keywords: social influence, support networks, information flow, trust, competencies

Paper type: Research paper 


\section{Introduction}

Traditionally, researchers considered social influence from the perspective of individuals influencing others, i.e., manipulations to compel obedience or induce a shift of attitudes. A variety of techniques are used to achieve social influence, such as persuasion, entrapment or manipulation. For individuals being influenced, the result is either simple obedience or compliance or more lasting identification with and internalization of the induced objectives.

However, another perspective to consider is that of the person who deliberately seeks to be influenced by others (Nowak et al., 2015). In that case falling under someone's influence is desired and actively pursued, whether through observation or seeking out the opinions of others.

This reversed approach of looking at influence from the perspective of the influenced rather than the influencer is especially critical for leaders and managers, because it allows them to take advantage of subordinates' or colleagues' resources in order to make more informed decisions.

To better understand the process and value of this approach, we sought to determine what sort of information individuals seek and how they organize the process of assembling support. After reviewing the traditional approaches to social influence, we will present the new reversed social influence theory, followed by the results of our research.

\section{Theory}

\subsection{Traditional approach to social influence}

Followers may adapt to a leader's ideas in numerous ways. Below our typical methods of persuasion.

\subsubsection{Obedience to authority}

One superficial way to produce conformity is through obedience to authority. This mechanism is most likely to occur within autocratic, directive and authoritarian leadership styles, where the leader's core interest is to impose desirable behavior.

This sort of "blind" obedience is often fleeting, and in the absence of authority, the imposed behavior may diminish or cease, especially if it's ethically unsavory. Furthermore, behaving under the pressure of an authority against one's own ethics may inflict severe mental harm. Stanley Milgram's [1] experiments of 1963 have been criticized as being highly unethical. Subjects suffered loss of dignity, shattered self-esteem and loss of trust in authority in general, even when authorities they encountered later appeared rational (Baumrind, 1964).
HOW MUCH DO LEADERS SEEK TO BE INFLUENCED?

Andrzej Nowak, Agata Zabłocka, Ryszard Praszkier 
HOW MUCH DO LEADERS SEEK TO BE INFLUENCED?

Andrzej Nowak, Agata Zabłocka, Ryszard Praszkier

\subsubsection{Entrapment and Manipulation}

A manipulative method that can result in a high degree of adaptation is entrapment. This occurs when people are first persuaded to obey easy commands and then feel compelled to obey more and more difficult commands, also known as the foot-in-the-door phenomenon (FITD). Studies have shown that carrying out an unpalatable but small request increased the likelihood that the subject would agree to a similar but even less palatable request made by the same person (Freedman and Fraser, 1966). The FITD phenomenon, if applied on purpose, is simply manipulation, understood as exerting devious influence over a person for one's own advantage (Braiker, 2004; Cialdini et al., 2004; Maxwell, 2013).

The FITD technique is often used in sales to entrap new clients. However, used purposely by leaders against their subordinates, it is pure manipulation (Freedman and Fraser, 1966). These tactics might work, often effectively, but they can also be quite destructive, exposing people to negative feelings and reinforcing dependency, helplessness and victimization (Braiker, 2004) [2]. In return, these negative feelings can limit subordinates' effectiveness as a source of information or innovation (Maxwell, 2013).

\subsubsection{Persuasion}

Persuasion, on the other hand, is a deliberate and non-manipulative attempt to influence others' beliefs, attitudes, intentions, motivations or behaviors, as opposed to exercising authority. It's also symbolic, making use of words, images, sounds, etc. (Wood, 2000; Gass and Seiter, 2013; Petty et al., 2003) to earn subordinates' cooperation through various means.

\subsubsection{Compliance}

The use of authority or persuasion may lead, at the very least, to compliance, meaning adaptation regardless of whether or not one agrees with the leader, as long as one's dissenting opinions are kept private. In other words compliance is about adjusting one's behavior (but not necessarily one's mind). Several studies have documented that greater external pressure generally leads to greater compliance with the wishes of the experimenter (Freedman and Fraser, 1966).

\subsubsection{Self-persuasion and Conformity}

A more sophisticated method of adaptation is self-persuasion. In this case, people are not coerced. Rather, remaining free to choose, they build up internal justifications for obedience. Leaders influence self-persuasion indirectly by placing people in situations where they are motivated to persuade themselves to change their own attitudes or behavior (Aronson, 1999). This seems a more "advanced" adaptation then mere obedience, as it involves modifications within the internal 
cognitive system, rather than external imposition. This form of adaptation is called conformity, which, as opposed to compliance, involves a change not only in behavior, but also in beliefs or thinking, in order to align with others or to align with normative standards (Deutsch and Gerard, 1955).

\subsubsection{Cognitive Dissonance}

What actually makes people change their beliefs and thinking? How does the conformity mechanism work? When people's actions conflict with their prior beliefs or attitudes, they often change these beliefs or attitudes to be more consistent with their own actions. Making a new choice that isn't consistent with these prior beliefs or attitudes kindles cognitive dissonance, which is then reduced through rationalization, i.e., the prior beliefs are changed to be more consistent with the actions. The phenomenon of cognitive dissonance is considered to be one of the most influential theories in psychology (Festinger, 1957; Festinger et al., 2009).

Leaders may (intentionally or otherwise) use the power of the situational context that influences the individual's cognitive structures and, in that way, societal mindsets. Consistency in cognition is one of the basic human drives acted out when people incorporate a new behavior into a self-image they desire to be cohesive. The new situational context prompts restructuring and achieving consistency on a new level; situational context influences cognitive structures, so that the person ends up incorporating the new behavior into a cohesive selfimage (Bem, 1967). If one begins an action, one will develop cognition that justifies this action intellectually, and the new cognitive structures will promote new attitudes and behaviors. For example, the purchase of a particular brand of automobile leads to the reading of advertisements or articles in praise of the brand purchased.

This sheds more light on the FITD phenomenon as well as on the process of conforming: One has to restructure internal beliefs in order to reduce the apparent cognitive dissonance and reach a state of internal cohesiveness on this new level. Most people want to perceive themselves as cohesive (Mischel, 1969, 1973).

\subsubsection{Majority Influence and Asch Experiment}

Another form of social influence is majority influence, in which the opinion of the majority sways the minority. The best illustration of this is the famous Asch experiment. In this study researchers gathered a group of seven to nine individuals in a classroom to take part in what appeared to be a simple experiment in visual discrimination. The task was simple: Participants were asked to say which of three lines of very different lengths was equal in length to a visually presented standard line. All but one of the participants were covert experiment assistants who each selected the same, noticeably wrong line. The subject was the last to 
HOW MUCH DO LEADERS SEEK TO BE INFLUENCED?

Andrzej Nowak, Agata Zabłocka, Ryszard Praszkier choose and chose the same wrong line as the others. There were 123 subjects in this and similar tests. In most cases (75 percent) the subjects choose the wrong line in conformity with the assistants. This shows the power of the pressure of the majority. Even if they are making obvious wrong choices, most people tend to conform to the majority's false opinions (Asch, 1956; McLeod, 2008).

Deutsch and Gerard (1955) hold that there are basically two psychological needs that lead humans to conform to the expectations of others: the need to be right (so called informational social influence) and the need to be liked (so called normative social influence). Those needs were apparently in conflict during the Asch experiment; the subjects must have been torn between a belief that they knew the right answer and acceptance of the others' consensus around another answer. Fortunately, 25 percent never conformed to the assistants' choice and instead, held to their own conviction.

\subsubsection{Minority influence}

Minority influence takes place when members of a minority group persuade a majority to accept their beliefs or behavior (Gardikiotis, 2011). This occurs when a small group or an individual acts as an agent of social change, by questioning established societal perceptions and proposing alternative ideas that challenge existing social norms. Results of minority influence are generally observable only after a period of time, as a tendency within the majority to accept the views expressed by the minority (McLeod, 2007).

In line with this framework, some researchers have modeled the "diffusion of innovations," [3] which led them to the "bubbles theory" (Vallacher and Nowak, 2007), in which "bubbles of new" appear and radiate in the "sea of old." This process is similar to the phenomenon of phase transitions in physics (Nowak and Vallacher, 2005), as when water, at a temperature of $212^{\circ} \mathrm{F}$, transforms into gas. In this scenario, one first observes a small nucleus of bubbles, which connect together, grow in size and become large, full-blown bubbles that eventually break the surface. Using bubbles as a metaphor for dynamical change, one can say that the bubbles are forerunners of the new state (metaphorical gas), becoming visible while the old state (liquid) can still be observed. Similarly, in societies undergoing rapid transition, we can find islands of the new reality intermixed with the old one. As change progresses the islands of "new" gradually expand at the expense of the "old." Under this model, interacting groups, rather than isolated individuals, are subject to change.

Bubble leaders are of central importance, especially at the beginning of these minority-driven transitions. They sow the seeds of the "new" and help the minority withstand the pressure of the majority during early stages of change. They can also foster connections among isolated clusters of "new" which can influence of the propagation of the idea (Nowak and Vallacher, 2005; Vallacher and Nowak, 2007). 
2.1.9. Identification and Internalization

On a higher level of leadership, the earlier mentioned mechanisms of executing authority, i.e., obedience, manipulation, compliance and conformity, would not be satisfactory. Democratic, participative, relationship-oriented, shared, distributed or transformational leadership (Chapter 2) gain buy in from followers by earning their identification with the leader's vision and/or objectives.

Identification with a leader happens when people are influenced by a leader who is liked and respected (Kelman, 1958). Research has shown that people predicting job satisfaction and high performance highlight identification with the leader as a significant factor for intellectual stimulation and personal recognition (Hobman et al., 2011).

Moreover, it was shown in Chapter 2 that transformational leadership is positively associated with personal identification with the leader, which supports followers' ability to innovate and willingness to commit to the organization. Vice versa, limited personal identification between leaders and followers can have a negative effect on the leader's effectiveness and stifle innovation and commitment to the success of organization (Zhu et al., 2013).

Probably the highest level of adaptation or acceptance is internalization, which happens when people adopt a belief or behavior both publicly and privately, without any internal conflict (Kelman, 1958). Through internalization people incorporate within themselves new values or attitudes and, in that way, become truly committed and loyal partners in pursuing desirable goals.

\subsubsection{Ego-based charisma}

Personality-based charisma, characterized as a compelling attractiveness or charm that can inspire devotion in others, was introduced into the literature by one of the founders of sociology, Max Weber (1978) and advanced by Tucker (1968) and Stark (1977).

The charismatic leader's inspiration, vision and risk-taking can help bring about radical change, especially in organizations trying to move out of lethargy (Conger, 1989). Charisma seen as a "magical gift" possessed by leaders, makes their followers strongly identify with the leader. The transformational leader, in contrast, inspires followers to pursue organizational goals instead of self-interests. Moreover, a transformational leader can operate without charisma and effectively influence team members using inspiration, intellectual stimulation and individual consideration (Barbuto, 1997). And in fact, as mentioned in the previous chapter, charisma is perceived as a debatable leadership characteristic, being either criticized as a "false" leadership trait (Solomon, 2014) or reframed as socialized charismatic leadership (Brown et al., 2005). 
HOW MUCH DO LEADERS SEEK TO BE INFLUENCED?

Andrzej Nowak, Agata Zabłocka, Ryszard Praszkier

\subsubsection{Mission-based charisma}

Social entrepreneurs' outstanding impact on the world around them wouldn't be possible without a special kind of social influence. They eschew control thorough obedience to authority or manipulation and avoid top-down, persuasive forms of social influence, yet they still have a significant effect on the mindsets and attitudes of people and groups. So how do they do it? The results of our analysis suggest that they use a specific Mission-Oriented Charisma.

"Mission-oriented" means that it isn't necessarily personality-based (as indicated by Weber). Instead, it's a specific radiating power associated with the particular mission being pursued and the passion behind the pursuit. Influence is achieved by summoning people to join in a movement for change and in coleading such a movement (Tucker, 1968). It's this form of charism that enables social entrepreneurs to initiate and pursue possible avenues of action (Edles and Appelrouth, 2014).

Concluding, it seems that social entrepreneurs demonstrate a specific kind of social influence. It would be worth exploring whether they also use reversed social influence, seeking to be influenced by others.

\subsection{Leaders seeking to be influenced}

Clearly, leaders looking to boost their organization's results often seek feedback and information. However, apart from being motivated to improve the group's performance, leaders may also be motivated to garner feedback for more selfish reasons, such as enhancing one's own image or protecting one's ego. (Ashford et al., 2003).

And it's not only the leader who benefits from seeking the opinions of others. Employees asked to share their thoughts feel wanted, included and motivated (Atwater and Brett, 2006). Such leader-member exchanges can positively influence overall satisfaction, commitment, role clarity and member competence and decrease turnover (Gerstne and Day, 1997). Moreover, creating individual networks of support helps build social capital and empower bottom-up initiatives, both in the social sector (Praszkier and Nowak, 2012; Zabłocka and Praszkier, 2012; Zabłocka et al., 2016), as well as in business (Praszkier, 2017).

\subsection{Reversed Social Influence}

Nowak et al. (2015) propose a different approach to social influence, looking from the perspective of the influenced. In this situation, the subject desires, and actively seeks to be influenced.

People wanting to be influenced observe others and ask for information and opinion. Social influence enables them to take advantage of the knowledge and resources of the sources of influence in order to optimize the decision-making process. 
Nowak et al. (2015) indicate that this is a frequent and often done automatically, e.g. by copying others' behavior (also see: Simon, 1955; Bentley et al., 2010). This is also visible in business: one of the studies documented that employees use feedback seeking as a strategy to enhance their creative performance. It appeared that seeking feedback is not only a strategy that facilitates individual adaptation, but also a resource for achieving creative outcomes. (de Stobbeleir et al., 2017). Also examined the feedback-seeking behavior of 387 managers documented that active feedback seeking is a central part of a total process of self-regulation for managerial effectiveness (Ashford and Tsui, 2017).

The basic precondition for information exchange is trust (Semler, 2004; Northouse, 2010; Gardner et al., 2011). Nowak et al. (ibid) posit that trust is the most important factor for identifying individuals by whom leaders would want to be influenced. They tend to seek advice from those who deliver accurate information, leaving out those they consider less meticulous.

Nowak et al. (2015) hold that the way leaders organize the flow of support is based on moral issues and competencies. We would also add creativity, as in many cases creativity becomes the key lever for organizational development (Allen et al., 2013; Basadur, 2004; Bass and Riggio, 2006; Burns, 2003; Praszkier, 2017).

The milieu providing influence by others could be seen as a collection of individual support networks. People weave diverse networks that can be viewed from two perspectives: one is affiliation (e.g., family, neighborhood, peers, old school buddies, or hobby or sport connections) the other is the goal (e.g., computer-savvy individuals helping with ICT challenges, peers at work having a knack for solving conflicts, experts providing advice for the best diet). Individual support networks are typically embedded, though some may remain separate. For example leaders may keep family members involved in their business dealings while keeping neighbors away.

We posit that leaders have five critical individual support networks or sources of desired social influence:

- family and close friends,

- professional connections,

- colleagues and peers (leisure and entertainment),

- social engagement,

- local and neighborhood networks.

Within these, leaders strive to secure two kinds of individual support: loworder, processed information and data; i.e., bare dates, numbers, names (type A), and high-order, processed information, i.e., opinions, advice, strategies and predictions (type B).

Our hypothesis is that leaders select type A supporters primarily based on their competencies and type B supporters primarily for their influence on moral issues and creativity. 
HOW MUCH DO

LEADERS SEEK TO

BE INFLUENCED?

Andrzej Nowak, Agata Zabłocka, Ryszard Praszkier

\section{Research}

\subsection{The pilot}

As the research field on this topic was new, it required preparation of novel research tools. We began with a multi-faceted and diverse pilot program, which included diverse subjects and various methods for gathering information (interviews, questionnaire).

The research was preceded by pre-pilot interviews $(\mathrm{No}=5)$ followed by pilot interviews with Polish subjects: seven social entrepreneurs and one business entrepreneur [4]. The focus of the interviews was to determine personality characteristics of the people to whom subjects would delegate responsibility and expect information or opinions. Moreover, the questions related to the size and type of individual support networks the subjects used, their embeddedness, and the number of people within each who would provide support in a crisis situation.

Based on the pilot interviews, a pilot questionnaire was developed. The focus was to identify the personality traits of type A supporters (providing low-order, processed information and data) and type B supporters (providing high-order, processed information). This online pilot questionnaire was addressed to school principals participating in education programs related to the psychology of management [5][6]. We received 42 responses (23 female and 19 male, age 26 to 65: $\mathrm{M}=48,81 ; \mathrm{SD}=11,73$; most participants had higher education, $\mathrm{No}=36$ ).

In pilot studies principals filled questionnaire consisting of 15 adjectives thinking of people type A or B (adjectives: experienced, competent, reliable, initiative, is analytically, loyal, willing to cooperate, raises trust, has difficulties with concentration, has a lot of theoretical knowledge, thinks synthetically, is creative, stays serious, is moral, has sincere intentions).

The factor structure of the tool was checked using factor analysis with Varimax rotation and in component method. KMO measure (0.62) and Bartlett's sphericity test $\chi^{2}(136)=297 ; \mathrm{p}<0.001$ indicate that the factor analysis is justified. A 3-factor solution was obtained, which together explains 52.3\% of the variance.

The first factor consists of the following adjectives: good in thinking, competent, experienced, thinks synthetically, has a lot of theoretical knowledge, is competent (professional). We can identify this dimension as competence.

Second factor consists of the following adjectives: loyal, raises trust, polite, honest, has sincere intentions, willing to cooperate, moral. We can identify this dimension as morality.

The third factor consists of the following adjectives: creative, has a lot of own initiative and we can identify this dimension as creativity.

The above three indicators were created as averages of results for individual adjectives. 
The pilot studies indicated that the research should encompass five basic individual support networks: professional, family, friends, neighborhood and social engagement, many of them commonly embedded. The persons from whom subjects expected support (information or opinion) are described according to three basic dimensions: competence, ethical fiber and creativity. Type B persons scored higher on those three dimensions than type A (competence: $t(41)=8,565$; $\mathrm{p}<0.001$; ethical fiber: $\mathrm{t}(41)=3,684 ; \mathrm{p}=0.001$; creativity: $\mathrm{t}(41)=7,598 ; \mathrm{p}<0.001)$.

Drawing from the pilot interviews and questionnaire, we developed the final questionnaire, which addressed both the type and size of individual support networks as well as the personality traits of type A and type B supporters. The questionnaire "Support Networks and Delegating Responsibility" was placed online [7][8]. Invitations to the research were sent to social activists (foundations and associations), entrepreneurs and students by Ariadna research platform. Principals were selected from Ariadna's database resources.

113 responses were received (52 female and 61 male, age 18 to $65: M=33,3$ $\mathrm{SD}=9,41$ ). The subjects assigned their professional activity (type of employment) to five categories; most of the subjects checked business $(\mathrm{No}=29)$, social field $(\mathrm{No}=28)$ and education $(\mathrm{No}=22)$. Other respondents were students $(\mathrm{No}=19)$ and self-employed $(\mathrm{No}=15)$.

\subsection{The research}

The pilot study indicated the framework for the core research with the addition of variables related to employment (business, social sector, education, students and self-employment).

The first step was a comparative analysis between type A and type B supporters related to employment. A variance analysis with repeated measurements disclosed the main effect of the number of type A and B people in the environment $[\mathrm{F}(1,108)=7,335 ; \mathrm{p}=0.008$; eta $2=0,064]$ and lack of significant effects: main effect of the location $[\mathrm{F}(4,108)=0,45 ; \mathrm{p}=0.768]$ and interactive effect of variables $[F(4,108)=0,45 ; p=0.768]$. This means that the subjects were surrounded by more type B people than type A people, independent of their employment.

The consecutive analysis related to the assessment of competence, moral issues and creativity of type A and type B individuals, depending on their employment:

\subsubsection{Competence}

The subjects rated type A supporters' competence higher than type B $[F(1,108)=9,511 ; p=0.003$; eta $2=0,081]$ independent of their employment. Moreover, self-employed subjects scored higher on competence $(M=4,27)$ than those from the social sector $(\mathrm{M}=3,58)$, regardless of whether they were type 
HOW MUCH DO LEADERS SEEK TO BE INFLUENCED?

Andrzej Nowak, Agata Zabłocka, Ryszard Praszkier

Table 1.

Comparison the level of competence between A and B type in different employment categories

Table 2.

Comparison the level of moral issue between $\mathrm{A}$ and $\mathrm{B}$ type in different employment categories
A or $\mathrm{B}[\mathrm{F}(4,108)=3,497 ; \mathrm{p}=0.01$; eta $2=0,115]$. There was no visible interaction between both variables $[\mathrm{F}(4,108)=1,784 ; \mathrm{p}=0.137]$.

\begin{tabular}{llll}
\hline type & employment & M & SD \\
\hline \multirow{2}{*}{ A } & education & 4,05 & 0,70 \\
\cline { 2 - 4 } & business & 4,12 & 0,59 \\
\cline { 2 - 4 } & self-employment & 4,39 & 0,72 \\
\cline { 2 - 4 } & social sector & 3,55 & 0,76 \\
\cline { 2 - 4 } & student & 4,06 & 0,65 \\
\cline { 2 - 4 } & total & 3,99 & 0,73 \\
\hline \multirow{2}{*}{ B } & education & 3,85 & 0,64 \\
\cline { 2 - 4 } & business & 4,00 & 0,60 \\
\cline { 2 - 4 } & self-employment & 4,15 & 0,77 \\
\cline { 2 - 4 } & social sector & 3,61 & 0,63 \\
\cline { 2 - 4 } & student & 3,71 & 0,72 \\
\cline { 2 - 4 } & total & 3,85 & \\
\hline
\end{tabular}

\subsubsection{Moral issues}

The moral level of B-type people was assessed higher than the A-type people $[\mathrm{F}(1,108)=11,639 ; \mathrm{p}=0.001$; eta2 $=0,097]$, independent of their employment. Additionally, self-employed respondents scored higher on moral issues $(M=4,31)$ than those engaged in the social sector $(M=3,65)$ - irrespective of whether they were type $\mathrm{A}$ or $\mathrm{B}[\mathrm{F}(4,108)=3,033 ; \mathrm{p}=0.021$; eta $2=0,101]$. The analysis also revealed a significant interactive effect between both variables $[\mathrm{F}(4,108)=4,099$; $\mathrm{p}=0.004$, eta2 $=0,132]$ : only in the students' group was there a visible difference in the assessment of the moral levels of the two groups. Furthermore, within the education group, the moral standing of type A supporters was rated higher than that of type B supporters - a difference from other employment groups.

\begin{tabular}{llcc}
\hline type & employment & $\mathbf{M}$ & SD \\
\hline \multirow{2}{*}{$\mathrm{A}$} & education & 4,01 & 0,60 \\
\cline { 2 - 4 } & business & 3,99 & 0,58 \\
\cline { 2 - 4 } & self-employment & 4,28 & 0,62 \\
\cline { 2 - 4 } & social sector & 3,59 & 0,76 \\
\cline { 2 - 4 } & student & 3,67 & 0,66 \\
\cline { 2 - 4 } & total & 3,88 & 0,68 \\
\hline
\end{tabular}




\begin{tabular}{llll}
\hline type & employment & M & SD \\
\hline \multirow{3}{*}{ B } & education & 3,94 & 0,63 \\
\cline { 2 - 4 } & business & 4,12 & 0,60 \\
\cline { 2 - 4 } & self-employment & 4,34 & 0,61 \\
\cline { 2 - 4 } & social sector & 3,71 & 0,81 \\
\cline { 2 - 4 } & student & 4,12 & 0,66 \\
\cline { 2 - 4 } & total & 4,01 & 0,69 \\
\hline
\end{tabular}

HOW MUCH DO LEADERS SEEK TO BE INFLUENCED?

Andrzej Nowak, Agata Zabłocka, Ryszard Praszkier

Table 2. Continued

\subsubsection{Creativity}

Respondents scored the creativity of type B people higher than that of type A participants $[\mathrm{F}(1,108)=3,659 ; \mathrm{p}=0.058$; eta2 $=0,033]$, regardless their employment category (though results were close to the borderline of statistical significance). Additionally, it appeared that the self-employed $(\mathrm{M}=4,18)$ scored higher on creativity than the social activists $(M=3,48)[F(4,108)=3,250 ; p=0.015$ eta $2=0,107]$. There was no significant interaction effect between both variables $[\mathrm{F}(4,108)=2,037 ; \mathrm{p}=0.094]$.

\begin{tabular}{llll}
\hline type & employment & M & SD \\
\hline \multirow{4}{*}{ A } & education & 3,95 & 0,82 \\
\cline { 2 - 4 } & business & 3,71 & 0,75 \\
\cline { 2 - 4 } & self-employment & 4,23 & 0,73 \\
\cline { 2 - 4 } & social sector & 3,36 & 0,73 \\
\cline { 2 - 4 } & student & 3,42 & 0,82 \\
\cline { 2 - 4 } & total & 3,69 & 0,81 \\
\hline \multirow{3}{*}{ B } & education & 3,86 & 0,69 \\
\cline { 2 - 4 } & business & 3,86 & 0,64 \\
\cline { 2 - 4 } & self-employment & 4,13 & 0,97 \\
\cline { 2 - 4 } & social sector & 3,61 & 0,79 \\
\cline { 2 - 4 } & student & 3,89 & 0,61 \\
\cline { 2 - 4 } & total & 3,84 & 0,74 \\
\hline
\end{tabular}

Table 3. Comparison the level of creativity between $\mathrm{A}$ and $\mathrm{B}$ type in different employment categories

\subsubsection{Social support networks}

Another analysis considered the size of the individual support networks, i.e., family and close friends, professional connections, colleagues and peers / leisure and entertainment, social engagement, and local and neighborhood) relative to the employment category, done through a series of One-Way ANOVA tests. 
HOW MUCH DO LEADERS SEEK TO BE INFLUENCED?

Andrzej Nowak, Agata Zabłocka, Ryszard Praszkier

Table 4. Number of participants in network (total)

Table 5.

Number of participants within a particular type of network
The results showed that the variety of support networks was consistent across employment categories $[\mathrm{F}(4,108)=0,353 ; \mathrm{p}=0,841]$, but the number of participants within a particular type of network differed.

\begin{tabular}{lcccc}
\hline employment & M & SD & F & p \\
\hline education & 24,77 & 4,93 & 1,288 & 0,279 \\
\hline business & 23,62 & 4,01 & & \\
\hline self-employment & 26,47 & 5,46 & & \\
\hline social sector & 24,43 & 3,32 & & \\
\hline student & 23,47 & 4,96 & & \\
\hline total & 24,40 & 4,45 & & \\
\hline
\end{tabular}

For example, self-employed subjects had a larger professional network than students [Welch: $\mathrm{F}(4,48,691)=3,721 ; \mathrm{p}=0,01]$. Also within the local and neighborhood network self-employed subjects had a larger support network than students [Welch: $\mathrm{F}(4,48,746)=3,553 ; \mathrm{p}=0,013]$. Among respondents the selfemployed also had larger social engagement networks than students and business people [Welch: $F(4,48,334)=4,078 ; p=0,006]$. No significant difference occurred between persons from different employment categories with regard to the size of the family and peers networks.

\begin{tabular}{|c|c|c|c|c|c|}
\hline network & grupa & $\mathbf{M}$ & SD & Welch & $\mathbf{p}$ \\
\hline \multirow{6}{*}{$\begin{array}{l}\text { family and close } \\
\text { friends - professional } \\
\text { connections }\end{array}$} & education & 1,23 & 2,266 & 0,865 & 0,492 \\
\hline & business & 0,83 & 1,513 & & \\
\hline & self-employment & 1,73 & 3,327 & & \\
\hline & social sector & 1,32 & 1,982 & & \\
\hline & student & 0,68 & 1,003 & & \\
\hline & total & 1,12 & 2,036 & & \\
\hline \multirow{6}{*}{$\begin{array}{l}\text { professional connec- } \\
\text { tions - colleagues and } \\
\text { peers / leisure and } \\
\text { entertainment, }\end{array}$} & education & 2,64 & 3,346 & 1,834 & 0,138 \\
\hline & business & 0,97 & 1,295 & & \\
\hline & self-employment & 1,73 & 1,792 & & \\
\hline & social sector & 1,96 & 3,024 & & \\
\hline & student & 1,37 & 1,707 & & \\
\hline & total & 1,71 & 2,437 & & \\
\hline
\end{tabular}




\begin{tabular}{|c|c|c|c|c|c|}
\hline network & grupa & $\mathbf{M}$ & SD & Welch & $\mathbf{p}$ \\
\hline \multirow{6}{*}{$\begin{array}{l}\text { professional con- } \\
\text { nections - local and } \\
\text { neighborhood }\end{array}$} & education & 0,86 & 1,457 & 1,613 & 0,187 \\
\hline & business & 0,38 & 0,775 & & \\
\hline & self-employment & 1,00 & 1,414 & & \\
\hline & social sector & 1,46 & 3,061 & & \\
\hline & student & 0,42 & 1,017 & & \\
\hline & total & 0,83 & 1,846 & & \\
\hline \multirow{6}{*}{$\begin{array}{l}\text { professional connec- } \\
\text { tions - social engage- } \\
\text { ment }\end{array}$} & education & 1,09 & 1,411 & 0,554 & 0,697 \\
\hline & business & 0,72 & 1,645 & & \\
\hline & self-employment & 1,67 & 2,637 & & \\
\hline & social sector & 1,21 & 1,595 & & \\
\hline & student & 1,16 & 2,267 & & \\
\hline & total & 1,12 & 1,855 & & \\
\hline \multirow{6}{*}{$\begin{array}{l}\text { family and close friends } \\
\text { - colleagues and peers } \\
\text { / leisure and enterta- } \\
\text { inmen }\end{array}$} & education & 1,64 & 1,706 & 0,973 & 0,431 \\
\hline & business & 1,28 & 1,279 & & \\
\hline & self-employment & 1,53 & 1,807 & & \\
\hline & social sector & 2,54 & 3,316 & & \\
\hline & student & 1,68 & 1,336 & & \\
\hline & total & 1,76 & 2,127 & & \\
\hline \multirow{6}{*}{$\begin{array}{l}\text { family and close friends } \\
\text { - local and neighbor- } \\
\text { hood }\end{array}$} & education & 0,77 & 1,152 & 0,427 & 0,788 \\
\hline & business & 0,59 & 0,907 & & \\
\hline & self-employment & 0,67 & 1,113 & & \\
\hline & social sector & 1,29 & 2,904 & & \\
\hline & student & 0,58 & 1,261 & & \\
\hline & total & 0,81 & 1,726 & & \\
\hline \multirow{6}{*}{$\begin{array}{l}\text { family and close friend } \\
\text { - social engagement }\end{array}$} & education & 0,64 & 0,727 & 1,105 & 0,365 \\
\hline & business & 0,69 & 1,072 & & \\
\hline & self-employment & 1,27 & 1,438 & & \\
\hline & social sector & 2,21 & 5,666 & & \\
\hline & student & 0,89 & 1,524 & & \\
\hline & total & 1,17 & 3,026 & & \\
\hline
\end{tabular}

Table 5. Continued 
HOW MUCH DO

LEADERS SEEK TO

BE INFLUENCED?

Andrzej Nowak, Agata Zabłocka, Ryszard Praszkier

Table 5.

Continued

\begin{tabular}{|c|c|c|c|c|c|}
\hline network & grupa & M & SD & Welch & $\mathbf{p}$ \\
\hline \multirow{6}{*}{$\begin{array}{l}\text { colleagues and peers } \\
\text { / leisure and enter- } \\
\text { tainment - local and } \\
\text { neighborhood }\end{array}$} & education & 0,77 & 1,066 & 0,692 & 0,601 \\
\hline & business & 0,93 & 1,510 & & \\
\hline & self-employment & 1,47 & 1,685 & & \\
\hline & social sector & 1,46 & 2,925 & & \\
\hline & student & 0,95 & 1,224 & & \\
\hline & total & 1,11 & 1,877 & & \\
\hline \multirow{6}{*}{$\begin{array}{l}\text { colleagues and peers / } \\
\text { leisure and entertain- } \\
\text { ment - social engage- } \\
\text { ment }\end{array}$} & education & 1,55 & 2,017 & 1,104 & 0,365 \\
\hline & business & 0,69 & 1,583 & & \\
\hline & self-employment & 1,33 & 1,799 & & \\
\hline & social sector & 2,36 & 5,775 & & \\
\hline & student & 1,11 & 2,105 & & \\
\hline & total & 1,42 & 3,305 & & \\
\hline \multirow{6}{*}{$\begin{array}{l}\text { local and neighborhood } \\
\text { - social engagement }\end{array}$} & education & 1,14 & 2,624 & 1,073 & 0,381 \\
\hline & business & 0,55 & 0,910 & & \\
\hline & self-employment & 1,33 & 1,799 & & \\
\hline & social sector & 1,82 & 5,703 & & \\
\hline & student & 0,58 & 1,170 & & \\
\hline & total & 1,09 & 3,198 & & \\
\hline
\end{tabular}

Summarizing this series of variance analyses, one may conclude that people new to the job market have smaller individual support networks in the areas of professional connections, neighborhood networks and social engagement than those already employed.

\subsubsection{Asking for facts or opinions?}

Subsequent analysis relates to the question: What are subjects from each employment category focused on when asking for advice or support? Are they searching for bare facts or opinions based on facts? Or are they merely looking for opinions. For answers to these questions we conducted an $\chi^{2}$ analysis. Results showed that subjects from various types of employment seek the same type of information from the following networks: social engagement network $\left[\chi^{2}(24)=26,340 ; p=0,336\right]$, family network $\left[\chi^{2}(24)=30,319\right.$; $\mathrm{p}=0,174]$, neighborhood network $\left[\chi^{2}(24)=11,278 ; \mathrm{p}=0,939\right]$ and peer network $\left[\chi^{2}(24)=15,069 ; p=0,919\right]$. 
Also no differences were identified between the various employment groups in the general amount of information, opinions based on facts and general opinions distributed by these support networks $-\left[\chi^{2}(24)=34,103 ; p=0,803\right]$. There were some differences identified in the type of desired information: in all employment groups, facts and opinions based on facts were sought significantly more often than mere opinions.

Table 6.

Example of distribution of answers in professional network

\begin{tabular}{|c|c|c|c|c|c|c|c|c|c|}
\hline status & & facts & $\begin{array}{c}\text { facts } \\
\text { based on } \\
\text { opinion }\end{array}$ & opinion & $\begin{array}{c}\text { facts } \\
\text { and } \\
\text { facts } \\
\text { based on } \\
\text { opinion }\end{array}$ & $\begin{array}{c}\text { facts } \\
\text { based on } \\
\text { opinian } \\
\text { and } \\
\text { opinion }\end{array}$ & $\begin{array}{c}\text { facts } \\
\text { and } \\
\text { opinion }\end{array}$ & $\begin{array}{c}\text { facts, } \\
\text { opinion } \\
\text { and } \\
\text { facts } \\
\text { based on } \\
\text { opinion }\end{array}$ & total \\
\hline \multirow{4}{*}{ education } & $\mathrm{N}$ & $6 a$ & $8 \mathrm{a}$ & $0 \mathrm{a}$ & $3 a$ & $0 \mathrm{a}, \mathrm{b}$ & $0 \mathrm{a}, \mathrm{b}$ & $5 b$ & 22 \\
\hline & $\%$ from status & $27,30 \%$ & $36,40 \%$ & $0,00 \%$ & $13,60 \%$ & $0,00 \%$ & $0,00 \%$ & $22,70 \%$ & $100,00 \%$ \\
\hline & $\begin{array}{l}\% \text { from } \\
\text { professional } \\
\text { network }\end{array}$ & $17,60 \%$ & $18,60 \%$ & $0,00 \%$ & $15,00 \%$ & $0,00 \%$ & $0,00 \%$ & $62,50 \%$ & $19,50 \%$ \\
\hline & $\%$ from total & $5,30 \%$ & $7,10 \%$ & $0,00 \%$ & $2,70 \%$ & $0,00 \%$ & $0,00 \%$ & $4,40 \%$ & $19,50 \%$ \\
\hline \multirow{4}{*}{ business } & $\mathrm{N}$ & $9 \mathrm{a}, \mathrm{b}$ & $11 \mathrm{a}, \mathrm{b}$ & $0 \mathrm{a}, \mathrm{b}$ & $9 \mathrm{~b}$ & $0 \mathrm{a}, \mathrm{b}$ & $0 \mathrm{a}, \mathrm{b}$ & $0 \mathrm{a}$ & 29 \\
\hline & $\%$ from status & $31,00 \%$ & $37,90 \%$ & $0,00 \%$ & $31,00 \%$ & $0,00 \%$ & $0,00 \%$ & $0,00 \%$ & $100,00 \%$ \\
\hline & $\begin{array}{l}\% \text { from } \\
\text { professional } \\
\text { network }\end{array}$ & $26,50 \%$ & $25,60 \%$ & $0,00 \%$ & $45,00 \%$ & $0,00 \%$ & $0,00 \%$ & $0,00 \%$ & $25,70 \%$ \\
\hline & $\%$ from total & $8,00 \%$ & $9,70 \%$ & $0,00 \%$ & $8,00 \%$ & $0,00 \%$ & $0,00 \%$ & $0,00 \%$ & $25,70 \%$ \\
\hline \multirow{4}{*}{$\begin{array}{l}\text { self- } \\
\text {-employment }\end{array}$} & $\mathrm{N}$ & $3 a, b$ & $7 \mathrm{a}, \mathrm{b}$ & $2 b, c$ & $1 \mathrm{a}$ & $1 \mathrm{c}$ & $0 \mathrm{a}, \mathrm{b}, \mathrm{c}$ & $1 \mathrm{a}, \mathrm{b}$ & 15 \\
\hline & $\%$ from status & $20,00 \%$ & $46,70 \%$ & $13,30 \%$ & $6,70 \%$ & $6,70 \%$ & $0,00 \%$ & $6,70 \%$ & $100,00 \%$ \\
\hline & $\begin{array}{l}\text { \% from } \\
\text { professional } \\
\text { network }\end{array}$ & $8,80 \%$ & $16,30 \%$ & $40,00 \%$ & $5,00 \%$ & $100,00 \%$ & $0,00 \%$ & $12,50 \%$ & $13,30 \%$ \\
\hline & $\%$ from total & $2,70 \%$ & $6,20 \%$ & $1,80 \%$ & $0,90 \%$ & $0,90 \%$ & $0,00 \%$ & $0,90 \%$ & $13,30 \%$ \\
\hline \multirow{4}{*}{ social sector } & $\mathrm{N}$ & $10 \mathrm{a}$ & $11 \mathrm{a}$ & $2 \mathrm{a}$ & $2 \mathrm{a}$ & $0 \mathrm{a}$ & $1 \mathrm{a}$ & $2 \mathrm{a}$ & 28 \\
\hline & $\%$ from status & $35,70 \%$ & $39,30 \%$ & $7,10 \%$ & $7,10 \%$ & $0,00 \%$ & $3,60 \%$ & $7,10 \%$ & $100,00 \%$ \\
\hline & $\begin{array}{l}\% \text { from } \\
\text { professional } \\
\text { network }\end{array}$ & $29,40 \%$ & $25,60 \%$ & $40,00 \%$ & $10,00 \%$ & $0,00 \%$ & $50,00 \%$ & $25,00 \%$ & $24,80 \%$ \\
\hline & $\%$ from total & $8,80 \%$ & $9,70 \%$ & $1,80 \%$ & $1,80 \%$ & $0,00 \%$ & $0,90 \%$ & $1,80 \%$ & $24,80 \%$ \\
\hline \multirow{4}{*}{ student } & $\mathrm{N}$ & $6 a, b$ & $6 a, b$ & $1 \mathrm{a}, \mathrm{b}$ & $5 \mathrm{a}, \mathrm{b}$ & $0 \mathrm{a}, \mathrm{b}$ & $1 b$ & $0 \mathrm{a}$ & 19 \\
\hline & $\%$ from status & $31,60 \%$ & $31,60 \%$ & $5,30 \%$ & $26,30 \%$ & $0,00 \%$ & $5,30 \%$ & $0,00 \%$ & $100,00 \%$ \\
\hline & $\begin{array}{l}\% \text { from } \\
\text { professional } \\
\text { network }\end{array}$ & $17,60 \%$ & $14,00 \%$ & $20,00 \%$ & $25,00 \%$ & $0,00 \%$ & $50,00 \%$ & $0,00 \%$ & $16,80 \%$ \\
\hline & $\%$ from total & $5,30 \%$ & $5,30 \%$ & $0,90 \%$ & $4,40 \%$ & $0,00 \%$ & $0,90 \%$ & $0,00 \%$ & $16,80 \%$ \\
\hline
\end{tabular}




\begin{tabular}{|c|c|c|c|c|c|c|c|c|c|}
\hline status & & facts & $\begin{array}{c}\text { facts } \\
\text { based on } \\
\text { opinion }\end{array}$ & opinion & $\begin{array}{c}\text { facts } \\
\text { and } \\
\text { facts } \\
\text { based on } \\
\text { opinion }\end{array}$ & $\begin{array}{c}\text { facts } \\
\text { based on } \\
\text { opinian } \\
\text { and } \\
\text { opinion }\end{array}$ & $\begin{array}{c}\text { facts } \\
\text { and } \\
\text { opinion }\end{array}$ & $\begin{array}{c}\text { facts, } \\
\text { opinion } \\
\text { and } \\
\text { facts } \\
\text { based on } \\
\text { opinion }\end{array}$ & total \\
\hline \multirow{4}{*}{ total } & $\mathrm{N}$ & 34 & 43 & 5 & 20 & 1 & 2 & 8 & 113 \\
\hline & $\%$ from status & $30,10 \%$ & $38,10 \%$ & $4,40 \%$ & $17,70 \%$ & $0,90 \%$ & $1,80 \%$ & $7,10 \%$ & $100,00 \%$ \\
\hline & $\begin{array}{l}\% \text { from } \\
\text { professional } \\
\text { network }\end{array}$ & $100,00 \%$ & $100,00 \%$ & $100,00 \%$ & $100,00 \%$ & $100,00 \%$ & $100,00 \%$ & $100,00 \%$ & $100,00 \%$ \\
\hline & $\%$ from total & $30,10 \%$ & $38,10 \%$ & $4,40 \%$ & $17,70 \%$ & $0,90 \%$ & $1,80 \%$ & $7,10 \%$ & $100,00 \%$ \\
\hline
\end{tabular}

Table 6.

Continued

Table 7.

Example of distribution of answers in professional network

\subsubsection{What matters: Competence or trust in people's good intentions?}

The consecutive analysis sought to determine what drives people from different employment clusters when seeking advice or support. Is it perceived competence, or is it trust in people's good intentions? To identify these data we conducted an $\chi^{2}$ analysis. This disclosed that there are no differences among the employment groups in terms of the general data (professional network $\left[\chi^{2}(8)=5,405 ; \mathrm{p}=0,714\right]$; family network $\left[\chi^{2}(8)=12,361 ; \mathrm{p}=0,136\right]$; peer network $\left[\chi^{2}(8)=7,664 ; \mathrm{p}=0,467\right]$; neighborhood network $\left[\chi^{2}(8)=12,347 ; \mathrm{p}=0,136\right]$; social engagement network $\left.\left[\chi^{2}(8)=15,440 ; p=0,51\right]\right)$. Taking a closer look, however, there are some differences within the networks. In the professional and the social engagement networks, competence was most sought. Whereas in the family network, subjects looked for trust in people's good intentions. Only those working in the social field placed equal value on competence and trust in good intentions. status

competence

trust in people's good intentions competence and trust in people's good intentions total

\begin{tabular}{llcccc}
\hline \multirow{3}{*}{ education } & $\mathrm{N}$ & $20 \mathrm{a}$ & $1 \mathrm{a}$ & $1 \mathrm{a}$ & 22 \\
\cline { 2 - 6 } & $\%$ from status & $90,9 \%$ & $4,5 \%$ & $4,5 \%$ & $100,0 \%$ \\
\cline { 2 - 6 } & $\%$ from type & $21,7 \%$ & $7,7 \%$ & $12,5 \%$ & $19,5 \%$ \\
\cline { 2 - 6 } b from total & $17,7 \%$ & $0,9 \%$ & $0,9 \%$ & $19,5 \%$ \\
\hline \multirow{3}{*}{ business } & $\mathrm{N}$ & $25 \mathrm{a}$ & $2 \mathrm{a}$ & $2 \mathrm{a}$ & 29 \\
\cline { 2 - 6 } & $\%$ from status & $86,2 \%$ & $6,9 \%$ & $6,9 \%$ & $100,0 \%$ \\
\cline { 2 - 6 } & $\%$ from type & $27,2 \%$ & $15,4 \%$ & $25,0 \%$ & $25,7 \%$ \\
\hline
\end{tabular}




\begin{tabular}{|c|c|c|c|c|c|}
\hline \multicolumn{2}{|l|}{ status } & competence & $\begin{array}{l}\text { trust in people's } \\
\text { good intentions }\end{array}$ & $\begin{array}{l}\text { competence and } \\
\text { trust in people's } \\
\text { good intentions }\end{array}$ & total \\
\hline \multirow{4}{*}{ self-employment } & $\mathrm{N}$ & $10 \mathrm{a}$ & $3 \mathrm{a}$ & $2 \mathrm{a}$ & 15 \\
\hline & $\%$ from status & $66,7 \%$ & $20,0 \%$ & $13,3 \%$ & $100,0 \%$ \\
\hline & $\%$ from type & $10,9 \%$ & $23,1 \%$ & $25,0 \%$ & $13,3 \%$ \\
\hline & $\%$ from total & $8,8 \%$ & $2,7 \%$ & $1,8 \%$ & $13,3 \%$ \\
\hline \multirow{4}{*}{ social sector } & $\mathrm{N}$ & $21 \mathrm{a}$ & $5 \mathrm{a}$ & $2 \mathrm{a}$ & 28 \\
\hline & $\%$ from status & $75,0 \%$ & $17,9 \%$ & $7,1 \%$ & $100,0 \%$ \\
\hline & $\%$ from type & $22,8 \%$ & $38,5 \%$ & $25,0 \%$ & $24,8 \%$ \\
\hline & $\%$ from total & $18,6 \%$ & $4,4 \%$ & $1,8 \%$ & $24,8 \%$ \\
\hline \multirow{4}{*}{ student } & $\mathrm{N}$ & $16 \mathrm{a}$ & $2 \mathrm{a}$ & $1 \mathrm{a}$ & 19 \\
\hline & $\%$ from status & $84,2 \%$ & $10,5 \%$ & $5,3 \%$ & $100,0 \%$ \\
\hline & $\%$ from type & $17,4 \%$ & $15,4 \%$ & $12,5 \%$ & $16,8 \%$ \\
\hline & $\%$ from total & $14,2 \%$ & $1,8 \%$ & $0,9 \%$ & $16,8 \%$ \\
\hline \multirow{4}{*}{ total } & $\mathrm{N}$ & 92 & 13 & 8 & 113 \\
\hline & $\%$ from status & $81,4 \%$ & $11,5 \%$ & $7,1 \%$ & $100,0 \%$ \\
\hline & $\%$ from type & $100,0 \%$ & $100,0 \%$ & $100,0 \%$ & $100,0 \%$ \\
\hline & $\%$ from total & $81,4 \%$ & $11,5 \%$ & $7,1 \%$ & $100,0 \%$ \\
\hline
\end{tabular}

\section{Conclusions}

Table 7.

This study is a first step toward verifying the theory of reversed social influence, leaving space and inspiration for further research.

Various research techniques confirmed that business or social leaders are not only passively being influenced (according to the traditional understanding of social influence) but are also actively seeking to be influenced. They do this by accessing several individual support networks, which provide various information and opinions. The research identified several support networks, mostly embedded with one another: family and close friends, professional connections, colleagues and peers (mostly relating to leisure and entertainment), social engagement (involvement in social actions), and a local / neighborhood network.

The research also offers a closer look at how subjects' employment status correlates with the size and type of their particular support networks. For example self-employed subjects had statistically significantly larger professional and neighborhood / local networks than the students. Moreover, the self-employed subjects had larger social engagement networks than those of students and 
HOW MUCH DO LEADERS SEEK TO BE INFLUENCED?

Andrzej Nowak, Agata Zabłocka, Ryszard Praszkier business people. These findings indicate that freelancers, who lack the support of a formal structure, are, to a large extent, seeking support from their various networks.

Interestingly, it was confirmed that people from different employment clusters seek advice or support from others based on perceived competence and trust in people's good intentions. More precise analysis revealed that, within the professional and social engagement networks, the most sought after trait is competence. Whereas, within the family network, it's trust in people's good intentions. Only those working in the social field equally valued competence and trust (which is understandable given social activists' field of engagement).

Finally, we identified two kinds of supporters who influence leaders: type A supporters (providing only information and data, i.e., bare dates, numbers and names) and type B supporters (providing high-order, processed information, i.e., opinions, advice, strategies and predictions). The subjects expected higher competence from type A people than from type B people and a higher moral level and more creativity from the type B people than from type A people.

The comparative analysis revealed that, regardless of the subjects' type of employment, they surrounded themselves with more type B than type A supporters.

These findings reveal certain tendencies and open the avenue for further exploration of the patterns of reversed influence. The results so far are quite promising: leaders are willing to be influenced and are actively structuring specific personal support networks to provide this influence. It would be interesting, however, to delve deeper into the population of corporate managers of various levels to see if and how this reversed social influence phenomenon depends on the position in the company's hierarchy. Also it may be worth comparing the results with the structure-free "teal" kind of organizations (see: Laloux, 2014), where there is a freedom for bottom-up initiatives. Would the employees garnering their support from horizontal connections need as much extra-organizational support as those in hierarchic-structured companies?

\section{Funding}

The article is supported by a grant for Regulatory Social Impact from the Polish Committee for Scientific Research [DEC-2011/02/A/HS6/00231].

\section{Notes}

[1] Psychologist at Yale University.

[2] Some kinds of manipulation may be less destructive, e.g., ingratiation: a psychological technique in which an individual attempts to become more attractive or likeable to their target (Jones, 1964).

[3] The title of Everett Rogers' book: "Diffusion of Innovations," Rogers (2003).

[4] October - November 2016.

[5] Training provided by Foundation Humanitates (www.humanites.pl) and supported by association Ashoka: Innovators for the Public (http://ashoka-cee.org/poland/en/). 
[6] January 2017.

[7] On the Ariadna Research Platform (https://panelariadna.pl).

[8] July 2017.

\section{References}

Allen, S.L., Smith, J.E., Da Silva, N. (2013), “Leadership Style in Relation to Organizational Change and Organizational Creativity: Perceptions from Nonprofit Organizational Members", Nonprofit Management and Leadership, Vol. 24 No. 1, pp. 23-42.

Aronson, E. (1999), “The power of self-persuasion”, American Psychologist Press, Vol. 54 No. 11, pp. 875-884.

Asch, S.E. (1956), "Studies of independence and conformity: I. A minority of one against a unanimous majority", Psychological Monographs: General and Applied, Vol. 70 No. 9, pp. 1-70.

Ashford, S.J. and Tsui, S.T. (2017), "Self-regulation for Managerial Effectiveness: The Role of Active Feedback Seeking”, Academy of Management, Vol. 34 No. 2, pp. 2561-2580.

Ashford, S.J., Blatt, R. and Walle, D.V. (2003), "Reflections on the Looking Glass: A Review of Research on Feedback-Seeking Behavior in Organizations", Journal of Management, Vol. 29 No. 6, pp. 773-799.

Atwater, L.E. and Brett, J.F. (2006), “360-Degree Feedback to Leaders: Does it Relate to Changes in Employee Attitudes?", Group and Organization Management, Vol. 31 No. 5, pp. 578-600.

Barbuto Jr, J.E. (1997), "Taking the charisma out of transformational leadership”, Journal of Social Behavior and Personality, Vol. 12 No. 3, pp. 689-697.

Basadur, M.S. (2004), "Leading others to think innovatively together: Creative leadership", The Leadership Quarterly, Vol. 15 No. 1, pp. 103-121.

Bass, B.M., Riggio, R.E. (2006), Transformational leadership, Lawrence Erlbaum Associates, Mahwah, New Jersey.

Bem, D.J. (1967), "Self-perception: an alternative interpretation of cognitive dissonance phenomena", Psychological Review, Vol. 74 No. 3, pp. 183-200.

Bentley, R., Ormerod, P., Batty, M. (2010), "Evolving social influence in large populations", Behavioral Ecology and Sociobiology, Vol. 65 No. 3, pp. 537-546.

Braiker, H. (2004), "Who's Pulling Your Strings?: How to Break the Cycle of Manipulation and Regain Control of Your Life", McGraw-Hill, New York.

Brown, M.E., Treviño, L.K., Harrison, D.A. (2005), "Ethical leadership: A social learning perspective for construct development and testing", Organizational Behavior and Human Decision Processes, Vol. 97 No. 2, pp. 117-134.

Burns, J.M. (2003), “Transforming leadership", Grove Press, New York.

Baumrind, D. (1964), "Some thoughts on ethics of research: After reading Milgram's Behavioral Study of Obedience", American Psychologist, Vol. 19 No. 6, pp. 421-423.

Cialdini, R.B., Goldstein, N.J. (2004), "Social Influence: Compliance and Conformity", Annual Review of Psychology, Vol. 55, pp. 591-621.

Conger, J.A. (1989), The charismatic leader: behind the mystique of exceptional leadership, Jossey-Bass, San Francisco.

de Stobbeleir, K.E.M., Ashford, S.J. and Buyens, D. (2017), "Self-Regulation of Creativity 
HOW MUCH DO LEADERS SEEK TO BE INFLUENCED?

Andrzej Nowak, Agata Zabłocka, Ryszard Praszkier at Work: The Role of Feedback-Seeking Behavior in Creative Performance", Academy of Management, Vol. 54 No.4, pp. 811-831.

Deutsch, M., Gerard, H.B. (1955), "A study of normative and informational social influences upon individual judgment", Journal of Abnormal and Social Psychology, Vol. 51 No. 3, pp. 629-636.

Edles, L.D., Appelrouth, S. (2014), "Sociological Theory in the Classical Era", SAGE Publications, Thousand Oaks.

Festinger, L. (1957), A theory of cognitive dissonance, Stanford University Press, Stanford.

Festinger, L., Riecken, H.W., Schachter, S. (2009), When prophecy fails, Pinter and Martin, London.

Freedman, J.L., Fraser, S.C. (1966), "Compliance without pressure: The foot-in-the-door technique", Journal of Personality and Social Psychology, Vol. 4 No. 2, pp. 195-202.

Gardikiotis, A. (2011). "Minority influence", Social And Personality Psychology Compass, Vol. 5 No. 9, pp. 679-693.

Gardner, W.L., Cogliser, C.C., Davis, K.M., Dickens, M.P. (2011), “Authentic leadership: A review of the literature and research agenda", Leadership Quarterly, Vol. 22 No. 6, pp. 1120-1145.

Gass, R.H., Seiter, J.S. (2013), Persuasion, social influence, and compliance gaining, Routledge, Harlow, Essex.

Gerstner, C.R., Day, D.V. (1997), "Meta-analytic review of leader-member exchange theory: Correlates and construct issues", Journal of Applied Psychology, Vol. 82, pp. 827 - 844.

Hobman, E.V., Jackson, C.J., Jimmieson N.L., Martin, R. (2011), "The effects of transformational leadership behaviours on follower outcomes: An identity-based analysis", European Journal of Work and Organizational Psychology, Vol. 20 No. 4, pp. 553-580.

Kelman, H. (1958), "Compliance, identification, and internalization: Three processes of attitude change", Journal of Conflict Resolution, Vol. 1, pp. 51-60.

Laloux, F. (2014), Reinventing Organizations, Nelson Parker, Brussels.

Maxwell, E. (2013), "Influence vs. Manipulation”, Social-Engineering.org, Vol. 4 No. 45, available at: http://www.social-engineer.org/newsletter/Social-Engineer.Org\%20 Newsletter\%20Vol.\%2004\%20Iss.\%2045.htm (accessed 24 August 2017).

McLeod, S. (2007), "Moscovici and Minority Influence”, Simply Psychology, available at: http://www.simplypsychology.org/minority-influence.html (accessed 24 August 2017).

McLeod, S. (2008), “Asch Experiment”, Simply Psychology, available at: http://www. simplypsychology.org/asch-conformity.html (accessed 24 August 2017).

Mischel, W. (1969), "Continuity and change in personality", American Psychologist, Vol. 24 No. 11, pp. 1012-1018.

Mischel, W. (1973), "Toward a cognitive social learning reconceptualization of personality", Psychological Review, Vol. 80 No. 4, pp. 252-283.

Northouse, P.G. (2010), Leadership: Theory and Practice, Sage Publications, Thousand Oaks.

Nowak, A., Vallacher, R.R. (2005), "Information and influence in the construction of shared reality", IEEE: Intelligent Systems, Vol. 1, pp. 90-93. 
Nowak, A., Ziembowicz, K., Zabłocka, A., Bartkowski, W. (2015), "Social Influence from the Perspective of the Influenced Subject: Theory and Simulation Models", Social Psychology, Vol. 10, No. 3/34, pp. 296-309.

Petty, R.E., Wheeler, S.C., Tormala, Z.L. (2003), "Persuasion and Attitude Change", in: Millon, T., Lerner, M.J. (Eds.), Handbook of Psychology, John Wiley and Sons, Hoboken, New Jersey, pp. 353-382.

Praszkier, R., Nowak, A. (2012), "Social Entrepreneurship: Theory and Practice”, Cambridge University Press, New York.

Praszkier, R. (2018), Empowering Leadership of Tomorrow, Cambridge University Press, New York.

Semler, R. (2004), The Seven-Day Weekend: Changing the Way Work Works, Portfolio, New York.

Simon, H.A. (1955), "A behavioral model of rational choice", The Quarterly Journal of Economics, Vol. 69 No. 1, pp. 99-118.

Solomon, R.C. (2014), "Ethical Leadership, Emotions and Trust: Beyond 'Charisma"”, in: Ciulla, J.B. (Ed.), Ethics, the Heart of Leadership, Praeger, Santa Barbara, pp. 83-102.

Stark, S. (1977), "Toward a Psychology of Charisma", Psychological Reports, Vol. 40 No. 3, pp. 683-696.

Tucker, R.C. (1968), "The Theory of Charismatic Leadership", Daedalus, Vol. 97 No. 3, pp. 731-756.

Vallacher, R.R., Nowak, A. (2007), "Dynamical social psychology: finding order in the flow of human experience”, in: Kruglanski, A.W., Higgins, E.T. (Eds.), Social psychology: Handbook of basic principles, Guilford Publications, New York, pp. 734-758.

Weber, M. (1978), Economy and Society, University of California Press, Berkley.

Wood, W. (2000), "Attitude Change: Persuasion and Social Influence", Annual Review of Psychology, Vol. 51, pp. 539-570.

Zabłocka-Bursa, A., Praszkier, R. (2012), "Social change initiated by social entrepreneurs", in: Nowak, A., Winkowska-Nowak, K., Bree, D. (Eds.), Complex Human Dynamics: From Mind to Societies, Springer, New York, pp. 153-169.

Zabłocka, A., Praszkier, R, Petrushak, E., Kacprzyk-Murawska, M. (2016), „Measuring the propensity for building social capital depending on ties-strength", Journal of Positive Management, Vol. 7 No. 4, pp. 19-39.

Zhu, W., Wang, G., Zheng, X., Liu, T., Miao, Q. (2013), "Examining the Role of Personal Identification With the Leader in Leadership Effectiveness: A Partial Nomological Network", Group Organization Management, Vol. 38 No. 1, pp. 36-67. 